\title{
Uji Stabilitas Fisik Formula Sediaan Gel Ekstrak Daun Kelor (Moringa Oleifera Lamk.)
}

\author{
Slamet slamet ${ }^{1}$, Bibah Dewi Anggun ${ }^{2}$, Dwi Bagus Pambudi ${ }^{3}$ \\ email: slamet93ffua@gmail.com \\ 1, 2, 3 Program Studi Sarjana Farmasi Fakultas Ilmu Kesehatan Universitas \\ Muhammadiyah Pekajangan Pekalongan
}

\begin{abstract}
Abstrak. Tanaman kelor mempunyai khasiat sebagai antibakteri. Penambahan ekstrak daun kelor (Moringa oleifera Lamk.) di dalam sediaan gel diperkirakan dapat mempengaruhi stabilitas fisik sediaan tersebut. Penelitian ini bertujuan menguji stabilitas fisik sediaan gel yang mengandung ekstrak daun kelor (Moringa oleifera Lamk.) pada berbagai konsentrasi $(1 \%, 3 \%$ dan $5 \%)$. Uji stabilitas fisik sedian gel dilakukan setelah penyimpanan selama 14 hari pada suhu ruangan dan uji cycling test $\left(2^{\circ} \pm 40^{\circ} \mathrm{C}\right)$. Parameter stabilitas adalah organoleptis, uji daya sebar, uji daya lekat, pH, viskositas dan cycling test. Hasil ketiga formulasi menunjukkan stabilitas yang sesuai persyaratan sediaan gel diuji pada pengamatan organoleptis, daya sebar, daya lekat, $\mathrm{pH}$, viskositas dan hasil uji cycling test.
\end{abstract}

Kata kunci : Gel, Kelor, Stabilitas Fisik Physical Stability Test Formula Ready Gel Moringa Leaf Extract (Moringa Oleifera
Lamk.)

Abstract. Moringa plants have efficacy as an antibacterial. The addition of moringa leaf extract (Moringa oleifera Lamk.) preparation required to affect the physical stability of the preparation. The study aims to test the physical stability of gel preparations containing Moringa oleifera Lamk. Leaf extract at various concentrations $(1 \%, 3 \%$ and $5 \%)$. gel formula physical stability test was carried out after storage for 14 days at room temperature and the cycling test $(2 \mathrm{o} \pm 40 \mathrm{o} C)$. The stability parameters are organoleptic, dispersion test, adhesion test, $\mathrm{pH}$, viscosity, cycling test. The results of the three formulations showed that stability according to the requirements of the gel preparation. Gel preparation tested on observations of organoleptic, spreadability, adhesion, $p H$, viscosity, and cycling test results.

Keyword: Gel, Moringa, Physical Stability 


\section{Pendahuluan}

Salah satu tumbuhan yang mempunyai khasiat sebagai obat yaitu daun kelor (Moringa oleifera Lamk). Tanaman kelor (Moringa oleifera Lamk.) anggota famili Moringaceae, berasal dari India, Pakistan, Bangladesh dan Afghanistan. Kelor biasa digunakan untuk pengobatan infeksi bakteri, infeksi fungi, penyakit menular seksual, antiinflamasi, malnutrisi dan diare.

Daun kelor (Moringa oleifera Lamk.) mengandung saponin $5 \%$, tanin $1,4 \%$ dan triterpenoid 5\%. Tanin, polifenol serta saponin diketahui dapat merusak sel bakteri dengan cara menghambat sintesis serta merusak membran sel.

Gel merupakan salah satu sediaan farmasi yang memiliki konsistensi setengah padat yang terdiri dari suatu dispersi yang tersusun baik dari partikel anorganik yang berukuran kecil maupun molekul organik yang berukuran besar dan saling diresapi cairan (Ansel, 1989).

Polimer-polimer yang digunakan dalam membuat gel meliputi gom alam tragacanth, pektin, carrageen, agar, asam alginat, serta bahan-bahan sintetis dan semi sintetis seperti metilsellulosa, hidroksi etil sellulosa, karboksimetil sellulosa dan karbopol yang merupakan polimer vinil sintetis dengan gugus karboksil yang terionisasi.

Dalam membuat suatu formulasi sediaan farmasi yang harus diperhatikan adalah kestabilan suatu zatnya. Hal ini menjadi penting karena memerlukan waktu yang relatif panjang sampai ke pengguna atau pasien serta dalam pembuatannya diproduksi dalam jumlah yang besar. Oleh karena itu sediaan yang diproduksi juga penting untuk dilakukan pengujian terhadap kestabilannya sesuai prosedur yang telah ditentukan. Sediaan gel dapat dikatakan stabil apabila masih berada dalam batas yang telah ditentukan selama dalam waktu periode penyimpanan dan penggunaan, dengan sifat dan karakteristiknya zat aktif di dalam sediaan tetap sama atau stabil dengan yang dimilikinya pada saat dibuat. Pada penelitian ini dilakukan uji stabilitas fisik sediaan gel yang mengandung ekstrak daun kelor (Moringa oleifera Lamk.).

\section{Metode}

\section{Alat dan bahan}

Alat yang digunakan dalam penelitian ini adalah gelas ukur, batang pengaduk, beaker glass, timbangan analitik, $\mathrm{pH}$ meter, alat uji daya sebar, alat uji daya lekat, mortir dan stamfer. Bahan yang digunakan dalam penelitian ini adalah Karbopol, TEA, propilen glikol, gliserin nipagin, nipasol, aquadest

\section{Pembuatan sediaan gel}

Tabel 1. Formulasi Sediaan Gel Ekstrak Daun Kelor (Moringa oleifera Lamk.)

\begin{tabular}{|c|c|c|c|c|}
\hline \multirow{2}{*}{$\begin{array}{l}\text { Nama } \\
\text { Bahan }\end{array}$} & \multicolumn{3}{|c|}{ Formula } & \multirow{2}{*}{$\begin{array}{l}\text { Fungsi } \\
\text { bahan }\end{array}$} \\
\hline & I & II & III & \\
\hline $\begin{array}{l}\text { Ekstrak } \\
\text { daun } \\
\text { kelor }\end{array}$ & $0,1 \mathrm{~g}$ & $0,2 \mathrm{~g}$ & $0,4 \mathrm{~g}$ & Zat Aktif \\
\hline $\begin{array}{l}\text { Karbopol } \\
940\end{array}$ & $2 \%$ & $2 \%$ & $2 \%$ & $\begin{array}{c}\text { Gelling } \\
\text { agent }\end{array}$ \\
\hline $\begin{array}{l}\text { Trietanol } \\
\text { amin } \\
(\mathrm{TEA})\end{array}$ & $3 \%$ & $3 \%$ & $3 \%$ & $\begin{array}{l}\text { Neutraliz } \\
\text { ing agent }\end{array}$ \\
\hline $\begin{array}{l}\text { Propilen } \\
\text { glikol }\end{array}$ & $15 \%$ & $15 \%$ & $15 \%$ & Kosolven \\
\hline Nipagin & $0,1 \%$ & $0,1 \%$ & $0,1 \%$ & Pengawet \\
\hline $\begin{array}{l}\text { Propil } \\
\text { paraben }\end{array}$ & $0,02 \%$ & $0,02 \%$ & $0,02 \%$ & Pengawet \\
\hline Gliserin & $8 \%$ & $8 \%$ & $8 \%$ & Humektan \\
\hline $\begin{array}{l}\text { Aquadis } \\
\text { ad }\end{array}$ & $100 \mathrm{ml}$ & $100 \mathrm{ml}$ & $100 \mathrm{ml}$ & Pelarut \\
\hline
\end{tabular}
digunakan kemudian sediaan gel dengan basis karbopol 940 dikembangkan dalam 10 bagian aquades di dalam mortir, didiamkan hingga mengembang. Kemudian ditambahkan TEA lalu dihomogenkan. Selanjutnya ditambahkan propilen glikol 
yang sebelumnya telah dilarutkan dengan air suling panas suhu $90^{\circ} \mathrm{C}$, diaduk hingga homogen. Ekstrak daun kelor (Moringa oleifera Lamk.) dicampur dengan gliserin, dicampur kedalam basis, ditambahkan sisa air kedalam basis dan diaduk hingga homogen. Kemudian dilakukan uji aktivitas antibakteri.

\section{Evaluasi Sediaan Gel \\ Organoleptis}

Pengamatan sediaan meliputi aroma, warna dan tekstur dari masingmasing formula sediaan gel yang diamati sebanyak 3 kali selama 1 bulan (Pratiwi et al., 2016)

\section{Homogenitas}

Pengamatan ini bertujuan untuk melihat perubahan secara signifikan pada sediaan akhir yang telah dibuat. Sediaan diuji dengan menggunakan dua buah kaca objek, dimana sampel diletakkan pada salah satu kaca objek dan diletakkan secara merata. Sediaan yang baik harus homogen dan bebas dari partikel yang masih menggumpal.

\section{Uji Daya Sebar}

Pengujian ini dilakukan dengan menimbang sebanyak 0,5 gram gel kemudian diletakkan dalam kaca bulat, kaca lainnya diletakkan diatasnya dan dibiarkan selama 1 menit. Setelah itu, ditambahkan 150 gram beban didiamkan 1 menit dan diukur diameter konstan.

\section{Uji Daya lekat}

Uji daya lekat dilakukan dengan menimbang 0,5 gram gel diletakkan di bagian tengah gelas objek dan ditutupi dengan gelas objek lain. Diberi beban $1 \mathrm{~kg}$ diatasnya selama 5 menit, gelas objek tersebut dipasang pada alat uji yang diberi beban 80 gram. Dihitung waktu yang diperlukan 2 gelas objek hingga terlepas.

\section{Viskositas}

Uji viskositas sediaan dilakukan menggunakan viscometer brookfield dengan cara menyelupkan spindel pada viscometer dalam 100 gram sediaan yang telah dimasukkan dalam beaker glass dan dengan kecepatan yang sesuai. Viskositas sediaan dilihat pada skala dalam alat setelah tercapai kestabilan. Untuk melihat stabilitas dari sediaan, uji viskositas ini dilakukan 3 kali selama 1 bulan.

\section{Penetapan derajat keasaman dan kebasaan (pH)}

Pengujian $\mathrm{pH}$ dilakukan dengan menggunakan kertas $\mathrm{pH}$ universal yang dicelupkan kedalam sampel gel yang telah diencerkan. Perubahan warna yang terjadi dicocokkan dengan standar $\mathrm{pH}$ universal. Sediaan gel umumnya memiliki nilai $\mathrm{pH}$ antara 4-6.

\section{Uji Stabilitas Fisik}

Uji stabilitas fisik sediaan dilakukan dengan cara Cycling test. Sediaan gel ekstrak daun kelor (Moringa oleifera L.) disimpan pada suhu $4{ }^{\circ} \mathrm{C} \pm 2{ }^{\circ} \mathrm{C}$ selama 24 jam (perlakuan ini adalah satu kali siklus). Percobaan diulang sebanyak 6 siklus. Kondisi fisik dan $\mathrm{pH}$ sediaan dibandingkan sebelum dan sesudah uji (Rachman, 2010).

\section{Hasil Penelitian}

\section{Uji Organoleptis.}

Uji terhadap sediaan gel dengan mengamati warna, bau dan homogenitas. Basis gel yang semula bening dengan ada penambahan ekstrak daun kelor (Moringa oleifera Lamk.) menjadi hijau kekuningan sampai hijau kehitaman dengan bau yang khas dari ekstrak. Hasil sediaan gel ekstrak daun kelor (Moringa oleifera Lamk.) tidak terdapat perubahan warna, bau khas ekstrak dan bentuk semi padat serta terdapat gelembung udara di dalam 
sediaan pada hari ke 0 sampai hari ke 5 dan stabil baik formulasi 1 , formulasi 2 dan formulasi 3. Pada hari ke 7 dan hari ke 14 setiap formulasi masih mempunyai aroma yang sama berupa bau khas ekstrak. Pada formulasi 1 mempunyai warna hijau kekuningan, formulasi 2 memiliki warna hijau tua pekat serta formulasi 3 mempunyai warna hijau kehitaman. Sedangkan bentuk sediaan pada hari ke 7 dan ke 14 masing- masing formulasi mempunyai bentuk semi padat dengan gelembung yang sedikit berkurang. Sedangkan pada pemeriksaan homogenitas menunjukkan ketiga formulasi sediaan gel ekstrak daun kelor (Moringa oleifera Lamk.) tetap homogen, tidak terdapat partiket padat yang terdapat didalam sediaan gel.

\section{Daya sebar.}

Daya sebar yang baik adalah salah satu indikator bahwa sediaan gel tersebut mudah dioleskan. Uji daya sebar bertujuan untuk mengetahui kecepatan penyebaran dan mengetahui kelunakan dari sediaan gel pada kulit. Berdasarkan hasil yang dimiliki tidak ada perbedaan nilai daya sebar yang berarti dari masing - masing formulasi. Hasil tersebut menunjukkan bahwa semua formulasi yang dibuat memenuhi persyaratan daya sebar yaitu berkisar antara diameter $5-7 \mathrm{~cm}$. Semakin lama waktu penyimpanan sediaan gel hasil daya sebar akan menjadi semakin besar. Hal tersebut dikarenakan sediaan gel akan menjadi semakin encer karena basis yang digunakan tidak bisa mempertahankan air yang terpenetrasi kedalam basis.

3. Uji daya lekat.

Uji daya lekat dilakukan untuk mengetahui lama gel melekat pada kulit sebelum sediaan gel dibersihkan. Daya lekat suatu sediaan berbanding lurus dengan viskositas. Semakin tinggi viskositas maka daya melekatnya juga semakin tinggi. Daya lekat yang terlalu kuat akan menghalangi pori- pori kulit apabila terlalu lemah maka efek terapik tidak akan tercapai (Hapsari, et al., 2014). Hasil uji daya lekat ketiga formula menunjukan hasil lebih dari 1 detik baik pada hari ke $1,3,5,7$,maupun 14. Hal ini menunjukan gel akan melekat lebih lama dan zat aktifnya bisa bekerja optimal.

4. Viskositas.

Uji viskositas berguna untuk mengetahui besarnya suatu kekentalan suatu sediaan gel, dimana nilai viskositas atau kekentalan tersebut menyatakan bahwa besarnya tahanan suatu cairan untuk mengalir. Viskositas gel biasanya sebanding dengan jumlah dan berat molekul bahan pengental yang ditambahkan.

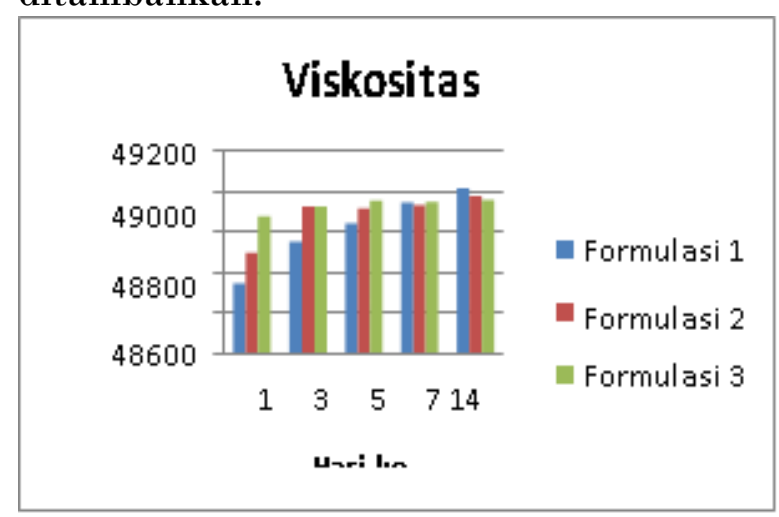

Gambar 1. Grafik Uji Viskositas

Hasil pengukuran viskositas sediaan gel ekstrak daun kelor (Moringa oleifera Lamk.) dapat dilihat pada gambar 1 dimana semakin lama waktu penyimpanan gel maka viskositas sediaan meningkat. Adanya perubahan viskositas pada sediaan gel disebabkan karena keberadaan gelembung udara pada sediaan yang masih terperangkap saat pembuatan gel. Gelembung pada sediaan gel mempengaruhi nilai viskositas, semakin banyak gelembung maka akan meningkatkan viskositas sediaan (. Hasil tersebut masih dalam batas yang dipersyaratkan yaitu standar viskositas dari sediaan gel adalah 5000-6000 .

\section{PH}

Pengukuran pH dilakukan sebagai parameter sifat fisikokimia dari suatu zat 
yang penting pada sediaan gel karena berkaitan dengan efektivitas zat aktif, stabilitas zat aktif dalam sediaan gel dan sediaan secara umum, maupun kenyamanan sewaktu digunakan pada kulit.

Hasil uji pH menunjukkan bahwa semua formulasi sediaan gel mengalami penurunan setelah dilakukan penyimpanan. Karbopol di dalam larutan berair mempunyai $\mathrm{pH} 2,5-4$ sehingga membutuhkan trietanolamin (TEA) sebagai pendapar. Penurunan $\mathrm{pH}$ sediaan gel disebabkan oleh gelling agent sediaan yaitu karbopol yang bersifat asam. Trietanolamin (TEA) tidak mampu menutupi sifat asam dari basis karbopol selama penyimpanan. Penurunan $\mathrm{pH}$ sediaan masih dalam rentang $\mathrm{pH}$ kulit sehingga masih dapat diterima.

\section{Cycling test}

Metode cycling test merupakan salah satu pengujian stabilitas sebagai simulasi adanya perubahan suhu (panas dan dingin) pada setiap tahun bahkan setiap hari. Oleh sebab itu uji ini dilakukan dalam kondisi beku pada suhu $2^{\circ} \mathrm{C}$ dalam lemari es serta kondisi meleleh pada suhu $40^{\circ} \mathrm{C}$ dalam oven pada interval waktu tertentu sehingga produk dalam kemasannya akan mengalami stress yang bervariasi. Uji stabilitas fisik ini berhubungan dengan daya tahansediaan gelselama penyimpanan.

Tabel 2. Hasil Uji Organoleptis Cycling Test Sedian Gel Daun Kelor (Moringa oleifera Lamk.)

\begin{tabular}{llll}
\hline \multirow{2}{*}{$\begin{array}{c}\text { For } \\
\text { m }\end{array}$} & Parameter & \multicolumn{2}{c}{ Pengamatan uji } \\
\cline { 3 - 4 } F1 & Warna & $\begin{array}{l}\text { Hijau } \\
\text { kekuningan }\end{array}$ & $\begin{array}{l}\text { Hijau } \\
\text { kekuningan }\end{array}$ \\
& & Khas & Khas \\
& Bau & ekstrak & ekstrak \\
& & $\begin{array}{l}\text { Semi padat, } \\
\text { terdapat } \\
\text { gelembun } \\
\text { Bentuk }\end{array}$ & $\begin{array}{l}\text { gelembung } \\
\text { udara } \\
\text { berkurang }\end{array}$ \\
& & gudara & Homogen \\
& & Homogen & \\
\hline
\end{tabular}

\begin{tabular}{|c|c|c|c|}
\hline \multirow[t]{5}{*}{ F2 } & Warna & $\begin{array}{l}\text { Hijau tua } \\
\text { pekat }\end{array}$ & $\begin{array}{l}\text { Hijau tua } \\
\text { pekat }\end{array}$ \\
\hline & Bau & Khas & Khas ekstrak \\
\hline & & ekstrak & \\
\hline & Bentuk & $\begin{array}{l}\text { Semi padat, } \\
\text { terdapat } \\
\text { gelembung } \\
\text { udara }\end{array}$ & $\begin{array}{l}\text { Semi padat, } \\
\text { gelembung } \\
\text { udara } \\
\text { berkurang }\end{array}$ \\
\hline & $\begin{array}{l}\text { Homogenit } \\
\text { as }\end{array}$ & Homogen & Homogen \\
\hline \multirow[t]{7}{*}{ F3 } & Warna & Hijau & Hijau \\
\hline & & kehitaman & kehitaman \\
\hline & Bau & Khas & Khas ekstrak \\
\hline & & ekstrak & \\
\hline & Bentuk & $\begin{array}{l}\text { Semi padat, } \\
\text { terdapat } \\
\text { gelembun }\end{array}$ & $\begin{array}{l}\text { Semi padat, } \\
\text { gelembung } \\
\text { udara }\end{array}$ \\
\hline & & g udara & berkurang \\
\hline & $\begin{array}{l}\text { Homogenit } \\
\text { as }\end{array}$ & Homogen & Homogen \\
\hline
\end{tabular}

Pemeriksaan organoleptis metode cycling test pada tabel 2 menunjukkan bahwa sediaan gel ekstrak daun kelor (Moringa oleifera Lamk.)memiliki bau berupa khas ekstrak, serta pada formulasi 1 mempunyai warna hijau kekuningan, formulasi 2 berwarna hijau tua pekat dan formulasi 3 mempunyai warna hijau kehitaman. Bentuk sediaan berupa semi padat serta tidak menunjukkan adanya kekeruhan, tetapi terdapat gelembung udara yang terperangkap dalam sediaan pada ketiga formulasi. Secara organoleptis sediaan masih sama atau tidak terjadi perubahan. Sedang pada pemeriksaan homogenitas menunjukkan ketiga formulasi sediaan gel tetap homogen, tidak terdapat partiket padat yang terdapat di dalam sediaan gel serta tidak ada pembentuk gel yang masih menggumpal atau tidak merata dalam sediaan baik sebelum maupun sesudah pengujian (cycling test). Hal ini menunjukkan bahwa komponen dalam ketiga formulasi terdispersi secara merata dan stabil. 


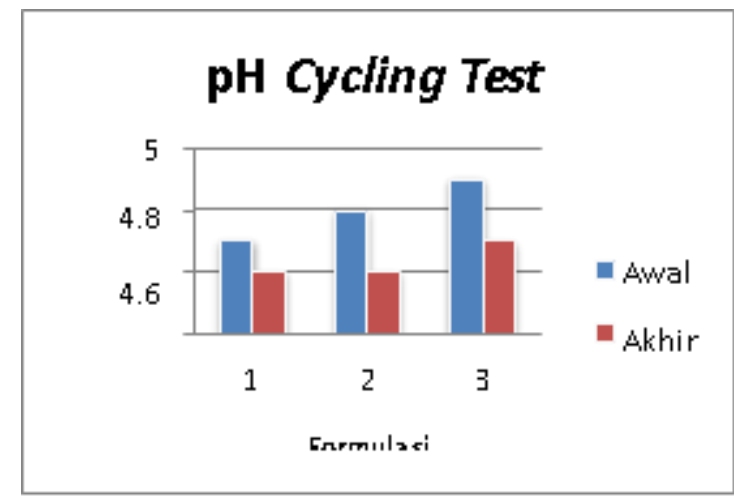

Gambar 2. Uji pH setelah cycling test Nilai $\mathrm{pH}$ sediaan setelah uji cycling test yang dapat dilihat pada gambar 4.5 hasil menunjukkan tidak ada perubahan dengan nilai $\mathrm{pH}$ selama pengamatan. Pada formulasi 1 mempunyai nilai $\mathrm{pH} \mathrm{4,7}$ sebelum pengujian dan setelah pengujian mendapatkan $\mathrm{pH} \quad 4,6$. Formulasi 2 mempunyai $\mathrm{pH}$ awal 4,8 dan setelah pengujian $\mathrm{pH} \quad 4,6$ sedangkan pada formulasi 3 mempunyai nilai $\mathrm{pH} 4,9$ dan 4,7 setelah dilakukan pengujian.

Sedangkan pada pengukuran viskositas mengalami penurunan pada setiap siklus. Hal ini dikarenakan adanya kenaikan suhu pada kondisi meleleh yaitu pada suhu $40^{\circ} \mathrm{C}$. Pemanasan suatu zat cair menyebabkan molekul-molekulnya bergerak sehingga gaya interaksi antar molekul melemah, dengan demikian viskositas sediaan gaya interaksi antar molekul melemah, dengan demikian viskositas sediaan akan turun dengan adanya kenaikan temperatur

\section{Simpulan}

Berdasarkan penelitian ini, didapatkan bahwa sediaan gel yang mengandung ekstrak daun kelor (Moringa oleifera L.) dengan konsentrasi $1 \%$. 3\% dan 5\% mempunyai parameter kestabilan fisik yang cukup baik.

\section{Terima kasih}

Terima kasih kami ucapkan pada pihakpihak yang telah membantu penelitian ini serta penulisan jurnal ini.

\section{Referensi}

Aminah, S, Tezar R, Muflihani Y. (2015). Kandungan Nutrisi dan Sifat Fungsional Tanaman Kelor (Moringa oleifera L.).Buletin Pengkajian Teknologi Pertanian. Jakarta. Vol 5, No.2.

Ansel. C. Howard. (2005). Pengantar Bentuk Sediaan Farmasi. Jakarta: Universitas Indonesia.

Black B. dan White E. T., (1997). The Effect of Aeration on The Viscosity of Molasses, Chemical Engineering Departmen. Universitas Of Queensland.

Garg, A., D. Aggarwal., S. Garg nd A. K Sigla. (2002). Spreading of Semisolid ormulation:An Update.

Pharmaceutical Technology. September 2002: 84- 102.

Hapsari I., Rosyadi A. dan Wahyuningrum R., (2014). Optimasi Kombinasi Minyak Atsiri Bunga Kenanga Dengan Herba Kemangi Dalam Gel Sebagai Repelan Nyamuk Aedes aegypti Dengan Metode Simplex Lattice Design. Fakultas Farmasi. UniversitasMuhammadiyah Purwokerto

Ikalinus, R, Sri K, Ni L.k. (2015). Skrining Fitokimia Ekstrak Etanol Kulit Batang Kelor (Moringa Oleifera). Universitas Udayana. Bali. Vol. 4 No.1 : 71-79.

Kementrian Kesehatan Republik Indonesia. (1995). Farmakope Indonesia Edisi ke-IV. Jakarta: Kementrian Kesehatan RI.

Lachman L. Liberman HA \& Kaning JL. (2007). Teori dan Praktek Farmasi Industri, Edisi Ketiga. Jakarta: Penerbit Universitas 
Indonesia.

Martin, A. (1993). Farmasi Fisik Edisi ke-III. Terjemahan dari Phisical Pharmacy. Oleh Joshita. Jakarta: UI Press

Prastianto B.A., (2016). Optimasi Gelling Agent Carbopol 940 dan Humektan Sorbitol Dlam Formulasi Sediaan Gel Ekstrak Etanol Daun Binahong (Anredera cordifolia (Ten.) Steenis). Skripsi. Fakultas Farmasi Universitas Sanata Dharma Yogyakarta.

Rachma, Muthia. (2010). Formulasi Sediaan Obat Kumur yang Mengandung Minyak Atsiri Temulawak (Curcuma xanthorriza) sebagai Antibakteri Pophyromonas gingivalis Penyebab Bau Mulut. Fakultas Matematika dan Ilmu Pengetahuan Alam. Program Studi Farmasi. Universitas Indonesia. Depok.

Rosmala Dewi, Anwar E., Ynita K S. (2014). Uji Stabilitas Formla Krim yang Mengandung Ekstrak Kacang Kedelai (Glycine max). Universitas Indonesia. Depok. Vol.1 No. 3.

Rowe. Raymond C, Paul J Sheskey, dan Marian E Quinn.(2009) Handbook of Pharmaceutical Excipients. 6 th edition. Chicago: Pharmaceutical Pre 
Jurnal Ilmiah Kesehatan Vol XIII, No II, September 2020 ISSN 1978-3167, E-ISSN 2580-135X 